\title{
PENGEMBANGAN MEDIA PEMBELAJARAN INTERAKTIF MENGGUNAKAN ADOBE FLASH CS6 PADA MATA PELAJARAN DASAR LISTRIK DAN ELEKTRONIKA KELAS X TEKNIK INSTALASI TENAGA LISTRIK (TITL) DI SMK DWIWARNA MEDAN
}

\author{
Sriadhi ${ }^{1}$, Nailul Zahrowi Yuwanda \\ ${ }^{1}$ PTIK, FT, UNIMED; ${ }^{2}$ PTE, FT, UNIMED \\ e-mail:Sriadhi01@yahoo.co.id ${ }^{1}$, nailulwanda40@gmail.com ${ }^{2}$
}

\begin{abstract}
Abstrak: Penelitian yang dilakukan ini bertujuan untuk mengembangkan media pembelajaran interaktif terhadap efektif dan efisiensi kegiatan belajar mengajar di SMK Dwiwarna Medan. Adapun metode penelitian yang digunakan merupakan metode penelitian Research and Development $(R \& D)$. Dan untuk model desain penelitian ini menggunakan desain ADDIE (Analysis, Desain, Development, Implementation, Evaluation). Data pada penelitian ini diperoleh melalui instrument yang diadaptasi dari Sriadhi: 2018, yang terdiri dari ahli materi, ahli media dan akseptansi peserta didik. Analisis data yang digunakan pada penelitian ini juga diadaptasi dari Sriadhi: 2018 melalui hitungan statistik deskriptif. Hasil dari penelitian ini didapatkan dari validasi ahli materi dengan kategori "Sangat Layak" yang memperoleh nilai rata-rata sebesar 4,7. Dan hasil validasi yang didapatkan dari ahli media dikategorikan "Sangat Layak" dengan mendapatkan nilai rata-rata sebesar 4,3.
\end{abstract}

Kata Kunci : Pengembangan, Media pembelajaran interaktif, Adobe Flash CS6, Dasar Listrik dan Elektronika.

\begin{abstract}
This research aims to develop interactive learning media for effective teaching and learning activities at SMK Dwiwarna Medan. This study used Research and Development $(R \& D)$ method. And for this research model using ADDIE design (Analysis, Design, Development, Implementation, Evaluation). The data in this study were obtained through an instrument that was first adapted from Sriadhi: 2018, which consisted of material experts, media experts and student acceptance. The data analysis used in this study was also adapted from Sriadhi: 2018 descriptive statistical calculations. The results of this study were obtained from the validation of material experts with the category "Very Appropriate" who obtained an average value of 4.7. And the validation results obtained from media experts was also categorized as "Very Appropriate " with an average value of 4.3 .
\end{abstract}

Keywords: Development, interactive learning media, Adobe Flash CS6, Basic Electricity and Electronics.

\section{PENDAHULUAN}

Pendidikan merupakan ujung tombak dalam mempersiapkan Sumber Daya Manusia (SDM) yang handal. Pendidikan dikyakini akan dapat mendorong memaksimalkan potensi siswa sebagai calon penerus generasi masa depan untuk bersikap kritis, logis dan inovatif dalam menghadapi dan menyelesaikan setiap permasalahan yang akan dihadapinya. Melalui pendidikan manusia dapat mengembangkan diri maupun memberdayakan potensi alam dan lingkungan untuk kepentingan hidupnya. Pendidikan juga dibutuhkan dalam membentuk karakter manusia yang baik, sehingga memiliki pendidikan yang baik merupakan kebutuhan yang sangat penting pada masa sekarang ini.

Teknologi dan pendidikan kejuruan di Indonesia telah memainkan peran penting dalam bidang sains dan teknologi di Indonesia yang memungkinkan lulusannya untuk mempersiapkan diri sebelum memasuki dunia kerja. Namun dengan demikian, fakta menunjukkan bahwa lulusan pendidikan teknologi kejuruan belum benar mencapai standart kompetensi.

Dari hasil observasi yang telah dilakukan di kelas X TITL SMK Dwiwarna Medan ditemukan beberapa permasalahan dalam proses belajar mengajar yang dilakukan, seperti kurangnya keterlibatan siswa dalam proses pembelajaran dan juga kurang efektifnya penggunaan media pembelajaran oleh guru. Akibatnya siswa menjadi kurang fokus dan kurang tertarik mendengarkan materi yang disampaikan oleh guru. Materi yang telah diterima oleh siswa belum sepenuhnya menggambarkan pengetahuan mata pelajaran yang sebenarnya, karena keterbatasan dari seorang guru, karena guru masih menyampaikan 
materi yang diajarkan dengan media yang kurang menarik.

Kurangnya media pendukung yang menarik juga membuat siswa kurang termotivasi dalam mengikuti pelajaran Dasar Listrik dan Elektronika sehingga siswa kesulitan dalam memahami teori dasar untuk melaksanakan praktik. Media pendukung ini dibutuhkan untuk meningkatkan keefektifan kegiatan proses pembelajaran sekaligus memaksimalkan fasilitas yang ada di program keahlian Teknik Instalasi Tenaga Listrik. Program keahlian ini memiliki fasilitas berupa komputer dan jaringan internet tapi guru dan siswa belum mengoptimalkan fasilitas tersebut. Padahal guru dan siswa mampu dan terbiasa menggunakan fasilitas komputer beserta jaringan internetnya. Dengan menggunakan Adobe Flash CS6 peneliti berinisiatif mengembangkan salah satu media pembelajaran interaktif yang diharapkan dapat dikembangkan dalam menyusun bahan ajar interaktif bagi siswa.

Berdasarkan penjelasan di atas diharapkan dengan menggunakan media yang dikembangkan ini dapat meminimalisir kejenuhan siswa dalam mengikuti mata pelajaran Dasar Listrik dan Elektronika pada kompetensi dasar mendeskripsikan pirantipiranti elektronika daya dalam rangkaian elektronik.

Tujuan dari penelitian ini antara lain, yaitu untuk mengetahui hasil rancang bangun media pembelajaran interaktif berbasis Adobe Flash CS6 pada mata pelajaran dasar listrik dan elektronika di kelas X TITL, mengembangkan media pembelajaran interaktif berbasis Adobe Flash CS6 pada kompetensi dasar mendeskripsikan piranti-piranti elektronika daya dalam rangkaian elektronik, mengetahui hasil validitas rancang bangun media pembelajaran interaktif menggunakan Adobe Flash CS6 yang dikembangkan sebagai media pembelajaran yang efektif untuk ahli media (pakar media), ahli materi (pakar konten).

\section{METODE}

Studi ini menggunakan metode Penelitian dan Pengembangan atau sering disebut Research And Develovment $(R \& D)$. dilaksanakan di Sekolah SMK Dwiwarna Medan kelas X Teknik Instalasi Tenaga Listrik (TITL). Sedangkan untuk subjek dalam penelitian ini adalah Dosen Universitas Negeri Medan dan juga guru di sekolah tempat penelitian dengan instrumen pengumpul data berupa lembar angket validasi guna mengetahui kelayakan terhadap media pembelajaran interaktif yang dikembangkan, adapun subjek terdiri dari 2 orang Dosen PTE, FT, UNIMED, 1 orang guru SMK Dwiwarna Medan, dan 2 orang Dosen PTIK, FT, UNIMED.

1. Langkah penelitian pengembangan media

Pengembangan media pembelajaran interaktif pada penelitian ini menggunakan model Borg and Gall (1983) yang merupakan salah satu model penelitian dan pengembangan pendidikan yang sangat populer untuk mengembangkan atau membuat sebuah produk media pembelajaran dalam pendidikan. Model desain yang digunakan dalam penelitian pengembangan ini adalah model berorientasi sistem. Model berorientasi sistem adalah model desain pembelajaran untuk menghasilkan suatu sistem pembelajaran yang cakupannya luas.

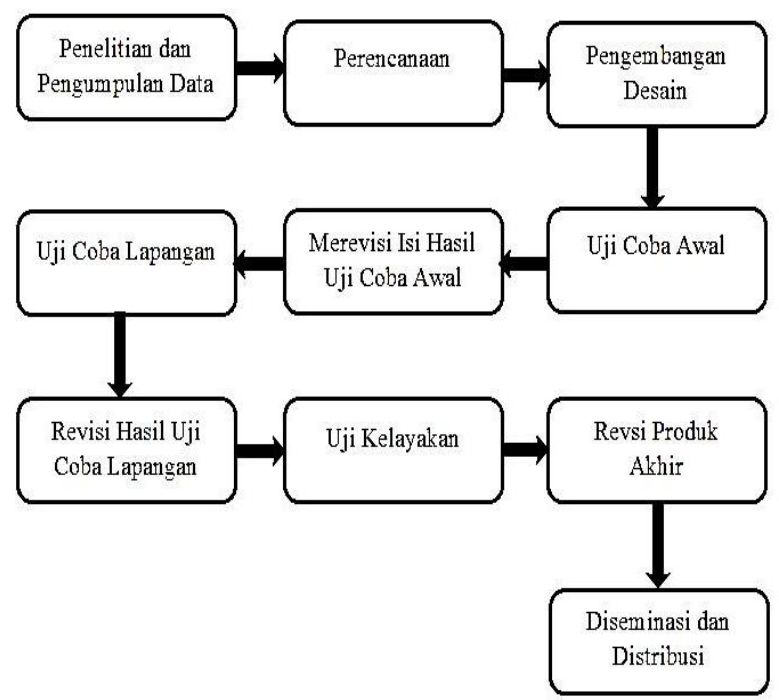

Gambar 1. Langkah-Langkah $R \& D$ Menurut Borg and Gall.

Penelitian dan pengembangan model pembelajaran yang dikombinasikan dengan model Borg and Gall adalah model desain pembelajaran ADDIE (Analysis, Desain, Development, Implementation, Evaluation). sehingga penelitian pengembangan menurut Borg and Gall terdapat kesamaan yang dipadukan menjadi satu.

Penelitian menggunakan model Borg and Gall terdapat 10 langkah yang telah disederhanakan menjadi 5 langkah dengan jalan menggabungkan beberapa siklus penelitian pengembangan ADDIE, untuk lebih jelas dapat ditunjukkan pada tabel berikut ini. 
Tabel 1. Kombinasi R \& D Borg and Gall dengan Model Desain ADDIE

\begin{tabular}{|c|c|}
\hline ADDIE & R \& D Borg and Gall \\
\hline 1. Analysis & $\begin{array}{l}\text { 1. Reseach and } \\
\text { Information Collecting }\end{array}$ \\
\hline 2. Design & 2. Planning \\
\hline $\begin{array}{l}\text { 3. Developme } \\
n t\end{array}$ & $\begin{array}{l}\text { 3. Develop Preliminary } \\
\text { From of Product }\end{array}$ \\
\hline $\begin{array}{l}\text { 4. Implementa } \\
\text { tion }\end{array}$ & $\begin{array}{ll}\text { 4. } & \text { Preliminary Field } \\
& \text { Testing } \\
\text { 5. } & \text { Main Product Revision } \\
\text { 6. } & \text { Main Field Testing } \\
\text { 7. } & \text { Operational Product } \\
& \text { Revision }\end{array}$ \\
\hline 8. Evaluation & $\begin{array}{ll}\text { 8. } & \text { Operational Field } \\
& \text { Testing } \\
\text { 9. } & \text { Final Product Revision } \\
\text { 10. } & \text { Dissemination and } \\
\text { Implementation }\end{array}$ \\
\hline
\end{tabular}

2. Prosedur Pengembangan Media Pembelajaran

Model desain ADDIE menjadi pedoman dalam pengembangan media pembelajaran interaktif ini dengan tahapan sebagai berikut.

a) Analisis (Analysis)

Pada tahap ini berfokus pada target audiens, dilakukan pendefenisian permasalahan intruksional, tujuan intruksional, sasaran pembelajaran serta dilakukan identifikasi lingkungan pembelajaran dan pengetahuan yang dimiliki oleh siswa. Ada dua pekerjaan yang dilakukan, yaitu a nalisis inerja dan analisis kebutuhan.

b) Desain (Design)

Tahap desain terkait dengan penentuan sasaran, instrument penilaian, latihan, konten, dan analisis yang terkait materi pembelajaran, rencana pembelajaran dan pemilihan media. Hal yang dilakukan adalah membuat rancangan media yang nantinya akan dibuat pada media pembelajaran, berikut merupakan storyboard media pembelajaran.

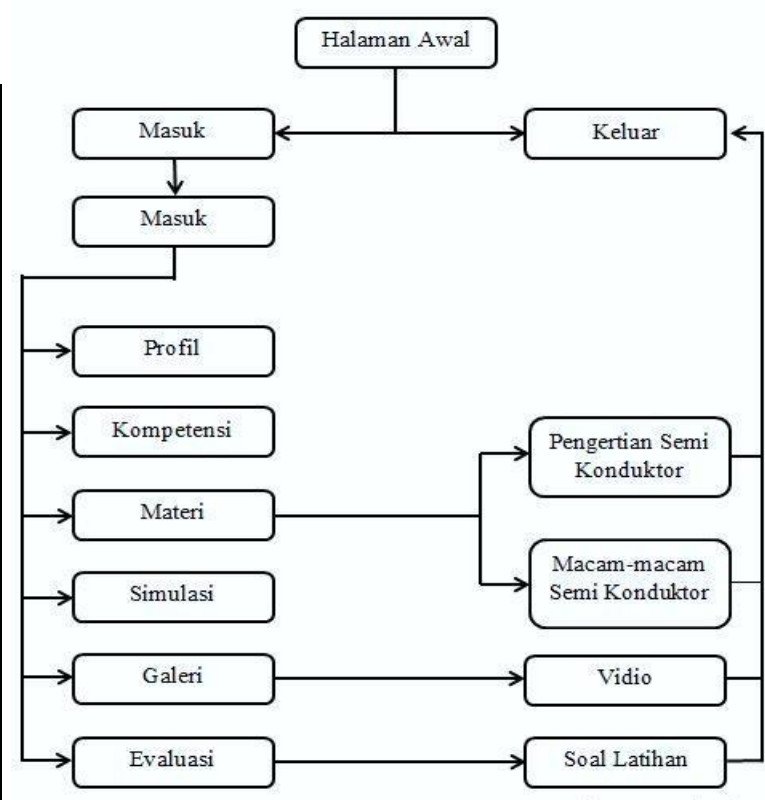

Gambar 2. Storyboard Media Pembelajaran

c) Pengembangan (Development)

Pengembangan adalah proses mewujudkan rancangan pada tahap desain menjadi kenyataan. Langkah pengembangan meliputi kegiatan membuat, memberi dan memodifikasi bahan ajar atau learning materials untuk mencapai tujuan pembelajaran yang telah di desain pada tahap desain. Pada tahap pengembangan dilakukan pembuatan dan penggabungan konten yang sudah dirancang pada tahap desain menggunakan software pendukung yaitu Adobe Flash. Tahap selanjutnya adalah tahap pengujian terhadap produk desain media pembelajaran yang telah dikembangkan. Validasi produk yang diuji berupa media pembelajaran interaktif di validasi oleh ahli media dan ahli materi, setelah divalidasi oleh kedua ahli masing-masing ahli materi dan media, selanjutnya akan memasuki tahap implementasi terhadap media yang telah dirancang.

d) Uji Coba (Implementation)

Uji coba adalah tahap pengujian produk desain yang telah dikembangkan berbasis multimedia interaktif kepada siswa Kelas X Teknik Instalasi Tenaga Listrik di SMK Dwiwarna Medan.

e) Evaluasi (Evaluation)

Tahap evaluasi adalah tahap perbaikan terhadap media yang telah diimplementasikan kepada siswa Kelas X TITL SMK Swasta Dwiwarna Medan 
untuk mendapatkan kelayakan dari media yang telah di desain, maka dilakukan evaluasi untuk diberi tanggapan oleh ahli media dan ahli materi.

3. Teknik Pengumpulan Data

Penelitian ini menggunakan instrument pengumpulan data berupa angket. Instrument untuk ahli media, ahli materi dan pengguna media yang dipakai dalam penelitian ini diadaptasi dari instrumen penilaian multimedia pembelajaran oleh (Sriadhi, 2018: 1-7).

4. Teknik Analisis Data

Adapun langkah-langkah teknis analisis data yang digunakan adalah sebagai berikut, yakni mengubah hasil penilaian ahli media, ahli materi dan akseptansi peserta didik yang masih dalam bentuk angka diubah menjadi skor dengan ketentuan yang dapat dilihat pada tabel.

Tabel 2. Aturan Pemberian Skor

\begin{tabular}{|l|l|}
\hline $5=$ sangat baik & $(85 \% \leq X \leq 100 \%$ \\
\hline 4 = baik & $(75 \% \leq X<85 \%)$ \\
\hline $3=$ kurang baik & $(65 \% \leq X<75 \%)$ \\
\hline $2=$ tidak baik & $(55 \% \leq X<65 \%)$ \\
\hline $1=$ sangat tidak baik & $(0 \% \leq X<55 \%)$ \\
\hline
\end{tabular}

Interpretasi kelayakan multimedia pembelajaran dan materi ajar dilakukan melalui hitungan statistik deskriptif. Skor jawaban dalam rentangan 1-5 ditabulasi dan dihitung skor ratarata. Tingkat kelayakan dibedakan dalam empat kelompok, dengan mean ideal $(2,50)$ sebagai skor batas kelayakan. Karena itu mean skor kurang dari mean ideal diinterpretasikan dalam kategori "tidak layak", sedangkan mean skor dalam kategori "layak" dibedakan dalam tiga tingkatan yaitu "kurang layak", "layak", dan "sangat layak", seperti dinyatakan dalam Tabel interpretasi berikut.

Tabel 3. Interpretasi Kelayakan Multimedia Pembelajaran

\begin{tabular}{|c|c|c|}
\hline No & $\begin{array}{c}\text { Interval Mean } \\
\text { Skor }\end{array}$ & Interpretasi \\
\hline 1 & $1,00-2,49$ & Tidak layak \\
\hline 2 & $2,50-3,32$ & Kurang layak \\
\hline 3 & $3,33-4,16$ & Layak \\
\hline 4 & $4,17-5,00$ & Sangat layak \\
\hline
\end{tabular}

\section{HASIL DAN PEMBAHASAN}

Adapun analisis kebutuhan lapangan menghasilkan media pembelajaran interaktif menggunakan Adobe Flash CS6. Penelitian dan pengembangan ini dilakukan di SMK Swasta Dwiwarna Medan. Penelitian ini menggunakan metode penelitian ADDIE (Analysis, Desain, Development, Implementation, Evaluation). Adapun langkah-langkah pengembangan produk akan dijelaskan sebagai berikut :

1. Potensi dan Masalah

Mengenai potensi dari penelitian dan pengembangan media pembelajaran ini adalah mengembangkan media pembelajaran interktif menggunakan Adobe Flash CS6 pada mata pelajaran Dasar Listrk dan Elektonika. Media pembelajaran interaktif yang dibangun ini digunakan untuk mengurangi permasalahan di kelas, karena guru atau pendidik yang masih menggunakan media cetak (buku) dalam kegiatan belajar mengajar, sehingga kegiatan proses belajar mengajar masih kurang menarik perhatian siswa.

Guru yang mengajar sebagai seorang pendidik masih menggunakan sebuah bahan ajar yang konvensional, seperti buku cetak dalam mengajar pembelajaran Dasar Listrik dan Elektronika. Adapun kelemahan dari buku cetak masih kurang mampu untuk menampilkan beberapa materi pembelajaran seperti menggunakan simulasi, sehingga peserta didik kesulitan untuk memahami materi pembelajaran yang bersifat abstrak. Selain itu kegiatan belajar mengajar yang monoton juga berdampak pada peserta didik yang akan mengakibatkan para peserta didik kurang tertarik dan mudah bosan.

2. Pengumpulan data

Didasarkan atas hasil identifikasi potensi dan masalah kemudian dilakukan langkah penelitian, yaitu pengumpulan data supaya dapat diketahui kebutuhan dari para peserta didik mengenai produk yang dikembangkan. Langkah pertama peneliti melakukan analisis kebutuhan dengan cara membagikan angket kepada para peserta didik. Berdasarkan angket tersebut diketahui peserta didik dalam kegiatan belajar mengajar Dasar Listrik dan Elektronika masih merasa kurang tertarik, karena belajar terkesan monoton dan membosankan. Tidak ada variasi dalam pembelajaran dan hanya menggunakan 
sumber belajar berupa buku cetak, sehingga perlu adanya suatu media pembelajaran yang dapat menarik minat peserta didik untuk mengikuti kegiatan belajar mengajar.

3. Desain produk

Adapun tahapan yang harus dilakukan dalam desain produk media pembelajaran interaktif menggunakan Adobe Flash CS6 pada mata pelajaran Dasar Listrik dan Elektronika, antara lain penentuan ide pembuatan media interaktif, analisis materi untuk membuat media interaktif, video pembelajaran, simulasi pembelajaran sederhana, dan gambar yang diambil dari beberapa situs internet, serta pada media terdapat juga beberapa video yang diunggah dari youtube. Setelah semua tahapan dimuat dalam Adobe Flash CS6, maka media pembelajaran interaktif akan dapat digunakan dan siap di publish ke dalam beberapa format publikasi.

Desain pengembangan media pembelajaran interaktif, dikerjakan menggunakan Adobe Flash CS6 dan dikemas dalam bentuk CD. Media pembelajaran ini dibangun dalam bentuk
CD bertujuan untuk mempermudah para peserta didik dalam belajar.

Hasil dari produk media pembelajaran interaktif yang telah berhasil dikembangkan untuk langkah penelitian selanjutnya dilakukan penyebaran instrument untuk dapat mengetahui kelayakan media dari validasi para ahli terhadap media pembelajaran interaktif Adobe Flash CS6. Validasi terhadap media pembelajaran ini dilakukan oleh ahli materi dan ahli media. Berdasarkan hasil dari validasi ahli materi dan validasi media pembelajaran diperoleh antara lain:

\section{Validasi Ahli Materi}

Ahli materi yang memvalidasi materi pembelajaran ini adalah dosen Pendidikan Teknik Elektro, FT, UNIMED, yaitu Dr. Agus Junaidi, S.T., M.T. dan M Aulia Rahman S. S.T., M.T. Serta guru SMK Dwiwarna Medan Husni Amril, S.T. Hasil validasi dari ahli materi terhadap produk Media Pembelajaran Interaktif Menggunakan Adobe Flash CS 6 pada mata pelajaran Dasar Listrik dan Elektronika Kelas X TITL di SMK Dwiwarna Medan diperlihatkan pada tabel berikut ini.

Tabel 4. Hasil Validasi Ahli Materi

\begin{tabular}{|c|c|c|c|c|c|c|c|}
\hline No & \multicolumn{2}{|c|}{ Aspek Materi } & $\begin{array}{l}\text { Panduan } \\
\text { dan } \\
\text { Informasi }\end{array}$ & $\begin{array}{c}\text { Materi } \\
\text { Multimedia }\end{array}$ & Evaluasi & Total & $\begin{array}{l}\text { Mean skor \& } \\
\text { Penilaian }\end{array}$ \\
\hline \multirow{2}{*}{1} & \multirow{2}{*}{ Penilai 1} & Jlh skor & 20 & 56 & 38 & 114 & \multirow{2}{*}{$\begin{array}{c}4.7 \\
\text { Sangat layak }\end{array}$} \\
\hline & & Jlh item & 4 & 12 & 8 & 24 & \\
\hline \multirow{2}{*}{2} & \multirow{2}{*}{ Penilai 2} & Jlh skor & 19 & 59 & 38 & 116 & \multirow{2}{*}{$\begin{array}{c}4.8 \\
\text { Sangat layak }\end{array}$} \\
\hline & & Jlh item & 4 & 12 & 8 & 24 & \\
\hline \multirow{2}{*}{3} & \multirow{2}{*}{ Penilai 3} & Jlh skor & 20 & 54 & 35 & 109 & \multirow{2}{*}{$\begin{array}{c}4.5 \\
\text { Sangat layak }\end{array}$} \\
\hline & & Jlh item & 4 & 12 & 8 & 24 & \\
\hline 4 & \multicolumn{2}{|l|}{ Total Skor } & 59 & 169 & 111 & \multicolumn{2}{|r|}{339} \\
\hline 5 & \multicolumn{2}{|l|}{ Mean Skor } & 4.9 & 4.6 & 4.6 & \multicolumn{2}{|r|}{4.7} \\
\hline 6 & \multicolumn{2}{|c|}{ Hasil Penilaian } & $\begin{array}{l}\text { Sangat } \\
\text { layak }\end{array}$ & $\begin{array}{l}\text { Sangat } \\
\text { layak }\end{array}$ & $\begin{array}{l}\text { Sangat } \\
\text { layak }\end{array}$ & \multicolumn{2}{|c|}{ Sangat layak } \\
\hline
\end{tabular}

Pada tabel validasi para ahli materi, maka didapatkan hasil rata-rata sebesar 4,9 dari aspek panduan dan informasi, 4,6 pada aspek materi multimedia, serta 4,6 pada aspek evaluasi. Sedangkan hasil keseluruhan validasi dari para ahli materi memperoleh rata-rata sebesar 4,7. Maka Hasil validasi terhadap produk media pembelajaran interaktif dari para ahli materi tersebut dikategorikan "Sangat Layak".

Untuk data analisis hasil dari para ahli materi terhadap media pembelajaran interktif yang dikembangkan dapat dilihat pada gambar grafik berikut ini. 


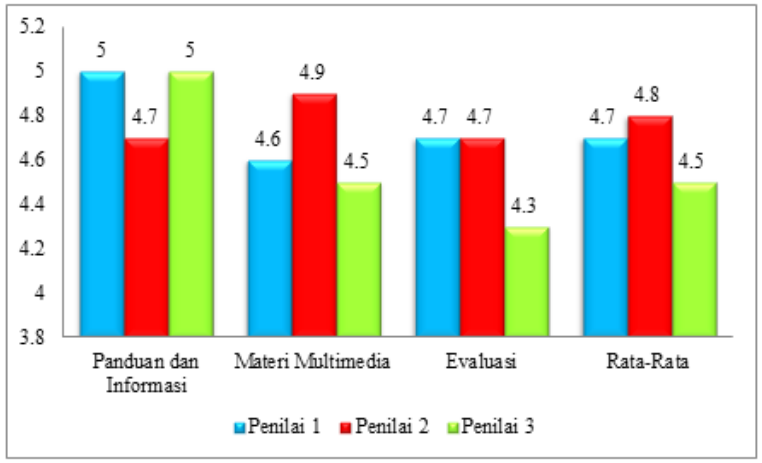

Gambar 3. Grafik Hasil Validasi Ahli Materi

\section{Validasi Ahli Media}

Ahli media yang memvalidasi media pembelajaran ini adalah dosen Pendidikan Teknologi Informatika dan Komputer, FT, UNIMED, yaitu Harvey Desmon Hutahean, S.Kom., M.Kom. dan juga Tansa Astono Putri, S.Kom., M.Kom. Validasi dari para ahli media bertujuan untuk melihat kualitas kelayakan dari media pembelajaran interktif menggunakan Adobe Flash CS 6 pada mata pelajaran Dasar Listrik dan Elektronika. Adapun hasil dari validasi para ahli media diperlihatkan pada tabel berikut ini.

Tabel 5. Validasi Ahli Media

\begin{tabular}{|c|l|l|c|c|c|c|c|}
\hline \multirow{2}{*}{ No } & \multicolumn{2}{|c|}{ Aspek Media } & $\begin{array}{c}\text { Panduan } \\
\text { dan } \\
\text { Informasi }\end{array}$ & $\begin{array}{c}\text { Operasional } \\
\text { Multimedia }\end{array}$ & $\begin{array}{c}\text { Sistematika, } \\
\text { Estetika, dan } \\
\text { Prinsip } \\
\text { Rekabentuk } \\
\text { Media }\end{array}$ & Total & $\begin{array}{c}\text { Mean skor \& } \\
\text { Penilaian }\end{array}$ \\
\hline \multirow{2}{*}{1} & \multirow{2}{*}{ Penilai 1 } & Jlh skor & 15 & 50 & 123 & 188 & 4.9 \\
\cline { 3 - 8 } 2 & Jlh item & 3 & 10 & 25 & 38 & Sangat layak \\
\hline 3 & \multirow{2}{*}{ Penilai 2 } & Jlh skor & 11 & 40 & 95 & 146 & 3.8 \\
\cline { 2 - 8 } & Jlh item & 3 & 10 & 25 & 38 & Layak \\
\hline 4 & \multicolumn{2}{|l|}{ Total Skor } & 26 & 90 & 218 & & 334 \\
\hline 5 & \multicolumn{2}{|l}{ Hasil Penilaian } & $\begin{array}{c}\text { Sangat } \\
\text { layak }\end{array}$ & $\begin{array}{c}\text { Sangat } \\
\text { layak }\end{array}$ & Sangat layak & \multicolumn{2}{|c|}{ Sangat layak } \\
\hline
\end{tabular}

Dilihat pada tabel hasil dari validasi para ahli media diperoleh rata-rata sebesar $\mathbf{4 , 3}$ pada aspek panduan dan informasi, dan $\mathbf{4 , 5}$ pada aspek operasional multimedia, serta $\mathbf{4 , 3}$ pada aspek sistematika, estetika, dan prinsip rekabentuk media. Sedangkan untuk hasil akhir dari validasi media didapatkan rata-rata sebesar $\mathbf{4 , 3}$, maka hasil akhir validasi dari para ahli media tersebut dikategorikan "Sangat Layak".

Untuk data analisis hasil dari para ahli media yang dikembangkan dapat dilihat pada gambar grafik berikut ini.

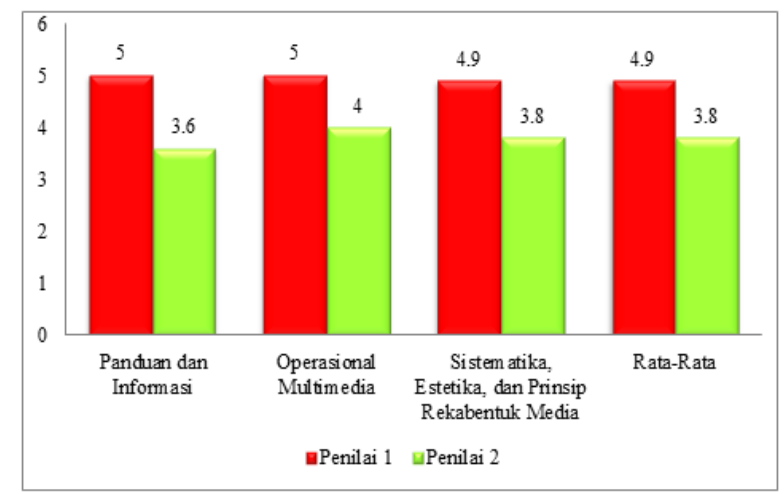

Gambar 4. Grafik Hasil Validasi Ahli Media
Revisi media dilakukan setelah media pembelajaran interaktif divalidasi oleh ahli materi dan ahli media. Saran dan masukan yang diberikan oleh para ahli digunakan sebagai acuan perbaikan media pembelajaran. Komentar dan saran perbaikan produk mencakup perbaikan keseluruhan dari aspek materi dan media.

Setelah memperbaiki media pembelajaran interaktif yang disarankan oleh ahli materi dan ahli media, maka produk akhir dari pengembangan media pembelajaran interaktif menggunakan Adobe Flash CS6 pada mata pelajaran Dasar Listrik dan Elektronika dapat digunakan pada jenjang SMK sebagai media pembelajaran yang interaktif. Berikut ini merupakan tabel produk akhir dari media pembelajaran interaktif menggunakan Adobe Flash CS6 pada mata pelajaran Dasar Listrik dan Elektronika.

Tabel 6. Produk Akhir Media Tampilan Media Pembelajaran 


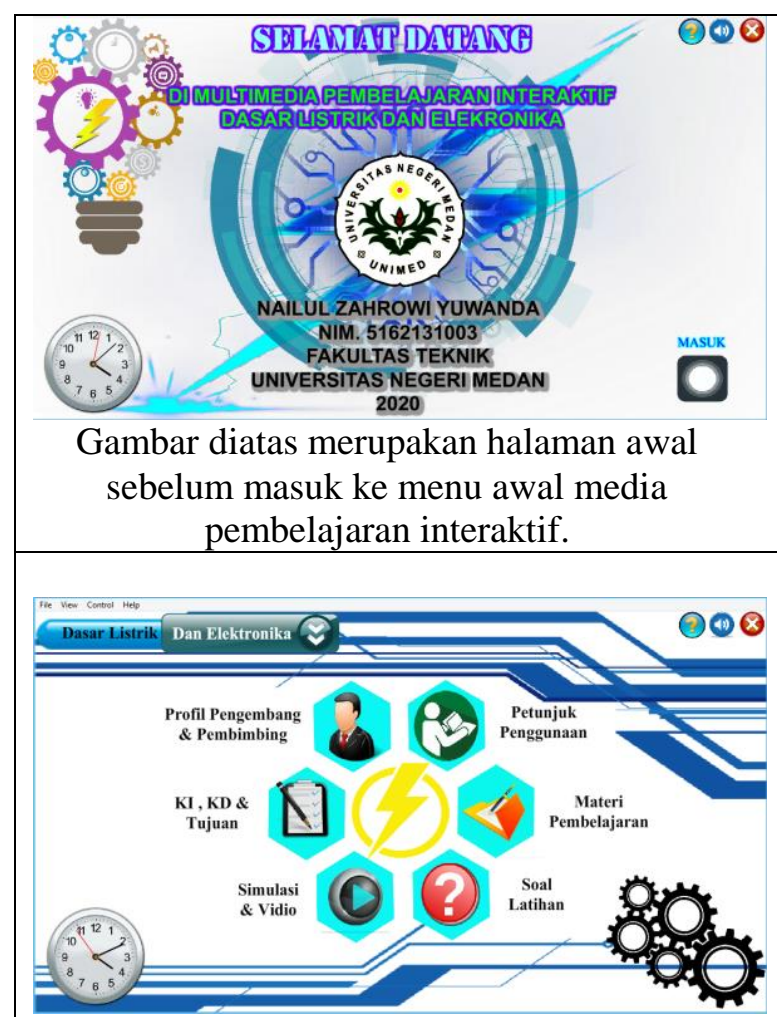

Gambar diatas merupakan tampilan dari menu utama media pembelajaran interaktif.

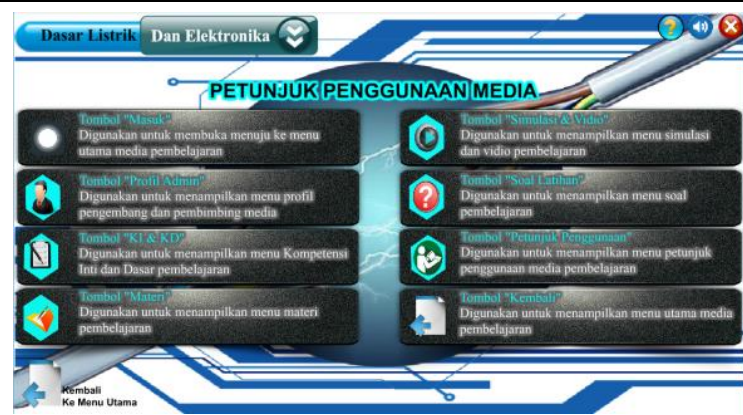

Gambar diatas merupakan tampilan dari menu petunjuk penggunaan media

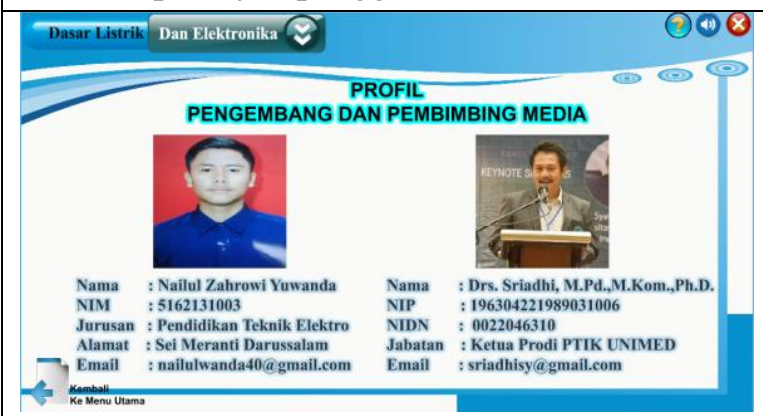

Gambar diatas merupakan tampilan dari menu profil pengembang dan pembimbing media pembelajaran interaktif

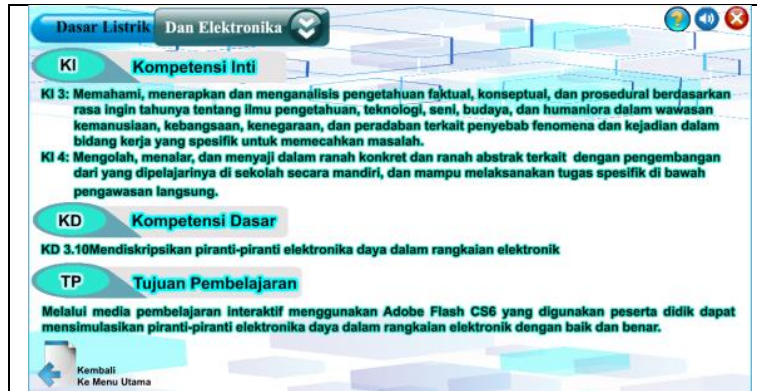

Gambar diatas merupakan tampilan dari menu KI, KD, dan Tujuan dari pembelajaran

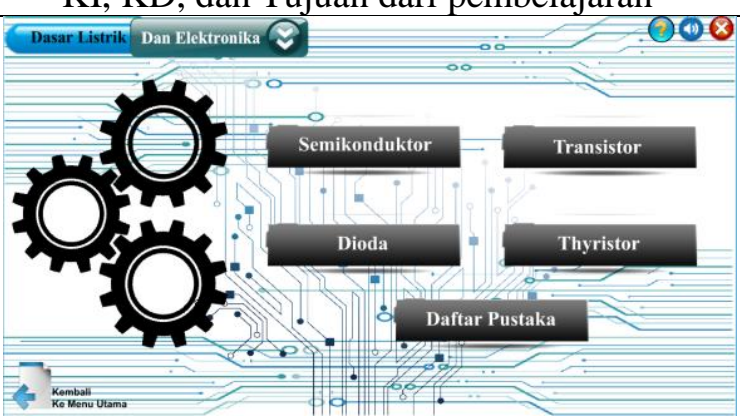

Gambar diatas merupakan tampilan untuk memilih sub maeri dari pembelajaran Dasar Listrik dan Elektronika

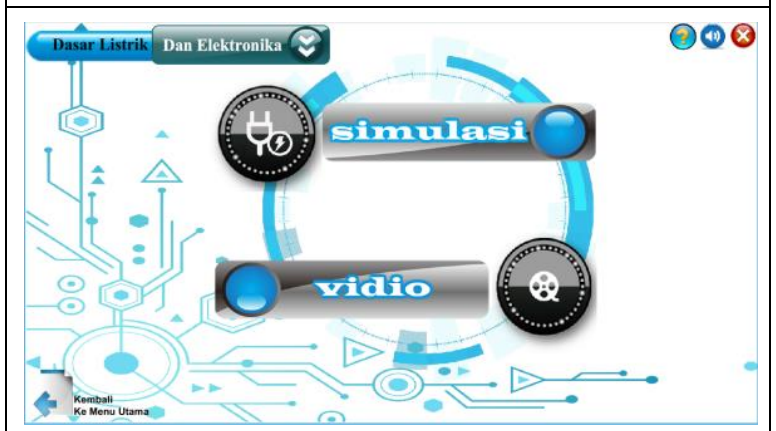

Gambar diatas merupakan tampilan dari menu simulasi \& vidio pembelajaran pada media interaktif ini

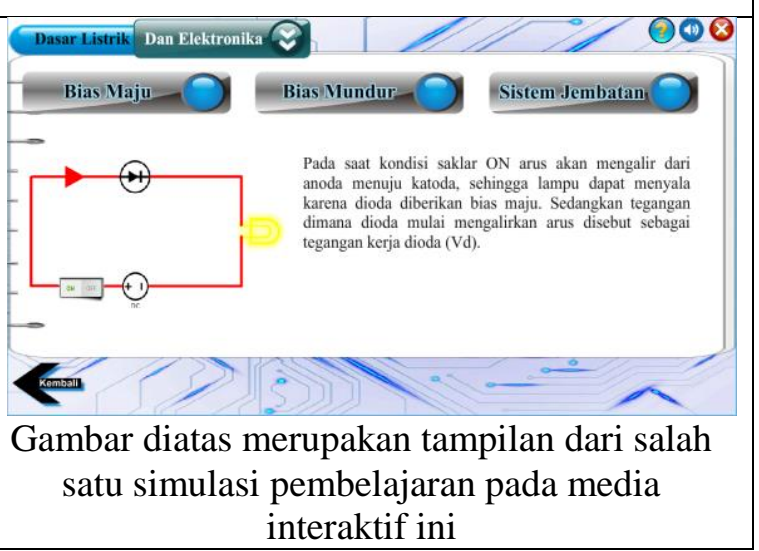




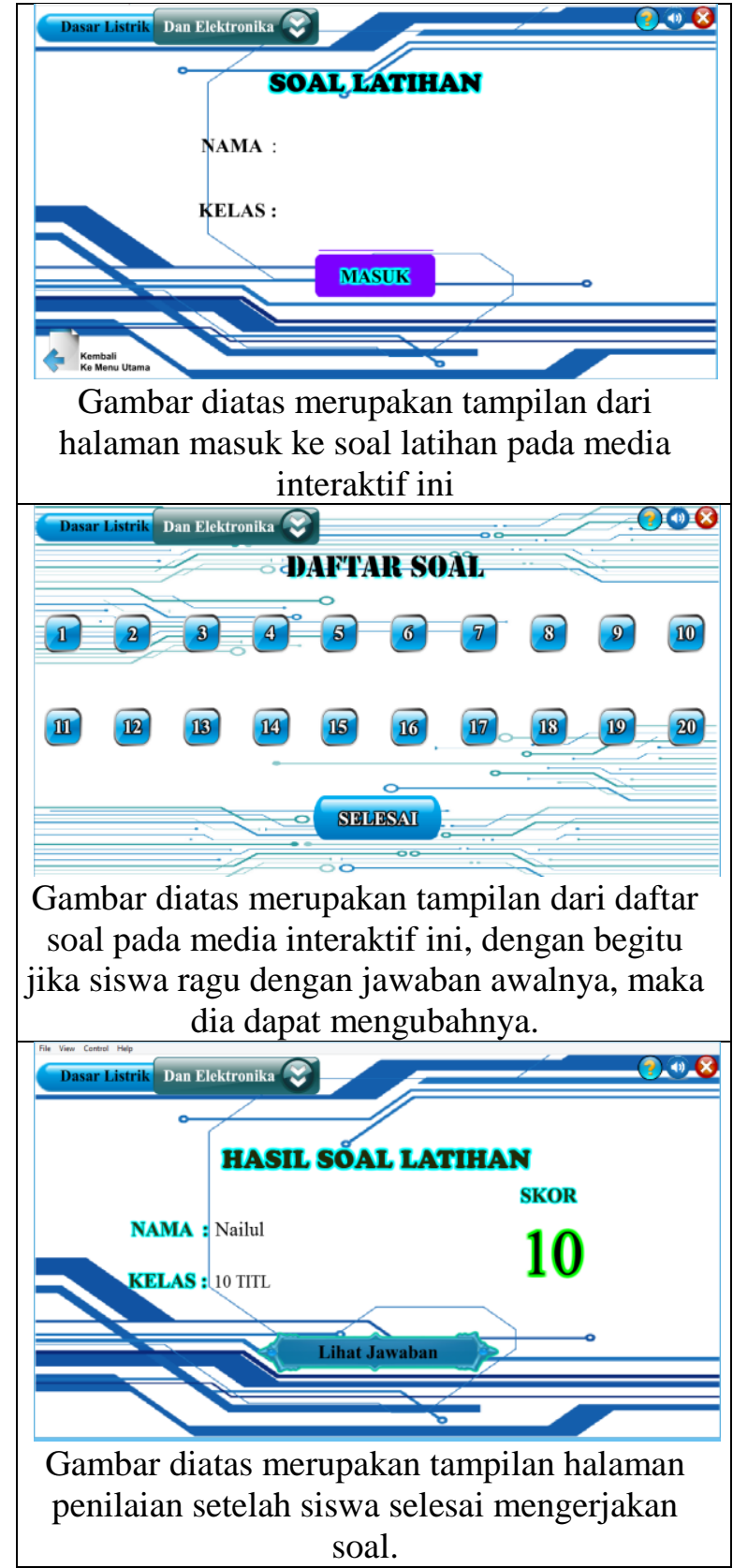

Tahapan pengembangan media pembelajaran interaktif menggunakan Adobe Flash CS6 pada mata pelajaran Dasar Listik dan Elektronika, yaitu dimulai dari perencanaan produk adalah dengan melakukan observasi di sekolah SMK Dwiwarna Medan. Pada tahap ini angket dibagikan kepada para peserta didik untuk mengetahui hal apa yang perlu diperbaiki dalam kegiatan belajar mengajar pada mata pelajaran Dasar Listrik dan Elektronika.

Berdasarkan dari hasil observasi dan juga penyebaran angket yang dilakukan, maka dapat dianalisis bahwa dalam proses kegiatan belajar mengajar media pembelajaran sangat perlu digunakan supaya dapat meningkatkan minat belajar serta memotivasi bagi para peserta didik dalam kegiatan pembelajaran Dasar Listrik dan Elektronika.

Pada Sekolah SMK Dwiwarna Medan.telah tersedia fasilitas penunjang proses kegiatan belajar mengajar seperti laboratorium komputer, LCD/Proyektor, yang dapat dimanfaatkan dalam proses kegiatan belajar mengajar supaya kegiatan pembelajaran menjadi lebih menarik. Media pembelajaran interaktif menggunakan Adobe Flash CS6 yang dikembangkan lalu kemudian divalidasi oleh tiga ahli materi, dan dua ahli media pembelajaran, sedangkan akseptansi untuk para peserta didik tidak dapat dilakukan dikarenakan masih terjadi wabah COVID 19, yang menyebabkan seluruh sekolah masih diliburkan.

Penelitian ini adalah penelitian R\&D dengan mengembangkan media pembelajaran interaktif menggunakan software Adobe flash CS6 pada mata pelajaran Dasar Listrik dan Elektronika. Penelitian ini dilakukan dengan menggunakan prosedur pengembangan model ADDIE.

Selanjutnya setelah observasi kebutuhan dilakukan, maka dilakukanlah pengumpulan data/informasi untuk mengetahui kebutuhan dari peserta didik terhadap produk yang ingin dikembangkan melalui penelitian dan pengembangan. Pengumpulan informasi dilakukan dengan wawancara kepada guru pendidik dan para peserta didik. Tahap berikutnya mengumpulkan referensi yang berkaitan dengan media pembelajaran interaktif yang menggunakan software Adobe flash CS6 pada mata pelajaran Dasar Listrik dan Elektronika Kelas X TITL.

Setelah tahap observasi dan pengumpulan data selesai kemudian langkah berikutnya adalah desain produk. Pada tahap desain produk media pembelajaran interaktif ini, diantaranya melakukan penyesuaian dengan standar kompetensi inti, kompetensi dasar dan tujuan dengan materi pembelajaran. Adapun desain produk pengembangan media pembelajaran interaktif yang menggunakan software Adobe Flash CS6 pada mata pelajaran Dasar Listrik dan Elektronika yang terdiri dari menu Profil, Kompetensi, Materi, Evaluasi, Video dan Simulasi.

Berikutnya akan dilakukan uji kelayakan setelah semua langkah-langkah diselesaikan. Uji kelayakan media dilakukan kepada ahli materi, dan ahli media, sedangkan uji akseptansi untuk para peserta didik tidak dapat dilakukan dikarenakan masih terjadi wabah COVID 19, yang menyebabkan seluruh sekolah masih diliburkan. 
Pada uji kelayakan ahli materi untuk media pembelajaran interaktif ini adalah dosen Pendidikan Teknik Elektro, FT, UNIMED, yaitu Dr. Agus Junaidi, S.T., M.T. dan M Aulia Rahman S. S.T., M.T. Serta guru SMK Dwiwarna Medan Husni Amril, S.T. Dan untuk ahli media pada media pembelajaran interaktif ini adalah dosen Pendidikan Teknologi Informatika dan Komputer, FT, UNIMED, yaitu Harvey Desmon Hutahean, S.Kom., M.Kom. dan juga Tansa Astono Putri, S.Kom., M.Kom.

\section{PENUTUP}

\section{Simpulan}

Berdasarkan dari hasil penelitian dan pembahasan yang telah diuraikan, maka dapat diambil beberapa kesimpulan sebagai berikut :

1. Dalam mengembangkan media pembelajaran interaktif diawali dengan melakukan penyebaran angket kepada para peserta didik untuk menganalisis masalah dalam kegiatan belajar mengajar. Selanjutnya melakukan pendesaian media pembelajaran interaktif yang sesuai dengan tujuan pembelajaran Dasar Listrik dan Elektronika yang berisi Profil, Kompetensi, Materi, Evaluasi, Video dan Simulasi. Tahapan akhir produk media pembelajaran ini adalah dengan melakukan validasi yaitu dengan ahli materi dan ahli media. Setelah melakukan validasi dari para ahli materi dan ahli media didapatkan saran dan masukan yang kemudian direvisi sehingga menjadi produk akhir media pembelajaran interaktif yang menarik.

2. Kelayakan media pembelajaran interaktif ini didapatkan dari hasil validasi ahli materi dengan kategori "Sangat Layak" yang memperoleh nilai rata-rata sebesar 4,7. Dan untuk hasil validasi berikutnya didapatkan dari ahli media dikategorikan "Sangat Layak" dengan mendapatkan nilai rata-rata sebesar 4,3. Dari keseluruhan hasil validasi, maka media pembelajaran interaktif yang dikembangkan layak digunakan pada jenjang SMK dalam proses kegiatan belajar mengajar.

\section{Saran}

Adapun saran yang diberikan ialah sebagai berikut :

1. Media pembelajaran interaktif menggunakan Adobe Flash CS6 yang dikembangkan pada penelitian ini hanya pada materi tentang mendeskripsikan piranti-piranti elektronika daya dalam rangkaian elektronik, jadi untuk penelitian selanjutnya perlu dikembangkan lebih lanut untuk materi yang lainnya dengan konten yang lebih baik lagi.

2. Dikarenakan pada saat ini masih dalam kondisi terkena wabah Virus Covid 19, maka untuk validasi akseptansi kepada peserta didik tidak dapat dilakukan, jadi untuk penelitian selanjutnya semoga dapat melakukan validasi akseptansi kepada peserta didik.

\section{DAFTAR PUSTAKA}

Arsyad, Azhar. (2013). Media Pembelajaran. Jakarta: Rajawali Pers.

Baharuddin. (2015). Pengembangan Media Pembelajaran Berbasis Multimedia Interaktif Sekolah Menengah Kejuruan Terhadap Efektif Dan Efisiensi Pembelajaran. Diakses Pada 19 Juli 2020 dari

http://journal2.um.ac.id/index.php/jinotep/ article/viewFile/2118/1253

Binanto, Iwan. (2010). Multimedia Digital-Dasar Teori dan Pengembangannya. Yogyakarta: Andi.

Dani Candra W. (2015). Pengembangan Media Pembelajaran Interaktif Mata Pelajaran Rangkaian Listrik untuk Kelas X Program Keahlian TITL SMK Muhammadiyah 3 Yogyakarta. Diakses pada 14 Februari 2020 dari

https://eprints.uny.ac.id/21875/1/Laporan \%20Skripsi.pdf

Darmawan, Deni. (2012). Teknologi Pembelajaran. Bandung: Remada Rosdakarya.

Daryanto, Tri. (2005). Sistem Multimedia dan Aplikasinya. Yogyakarta: Graha Ilmu.

Daryanto. (2010). Media Pembelajaran. Bandung: Satu Nusa.

Decky Trio Setyawan. (2019). Pengembangan Media Pembelajaran Interaktif Berbasis Adobe Captivate Pada Mata Pelajaran Dasar Listrik Dan Elektronika di SMK Negeri 7 Surabaya.Vol. 8, No. 1. Diakses pada 14 Februari 2020 dari

http://jurnalmahasiswa.unesa.ac.id/index.php/jur nal-pendidikan-teknikelektro/article/view/26016/23834.

Evasari. (2017). Modul Pembelajaran Teknik ElektronikaDasar-Dasar Listrik Dan Elektronika. Jakarta: Direktorat Pembinaan Sekolah Menengah Kejuruan.

Febby Dwi Al Indra dan Ika Parma Dewi. (2019). Rancang Bangun Media Interaktif Pada 
Mata Pelajaran Teknik Dasar Listrik Dan Elektronika. Diakses pada 14 Februari 2020 dari

http://ejournal.unp.ac.id/index.php/votekni ka/article/download/104465/101790.

Krismadinata, Fandy Arieska Wanda, dan Ridwan. (2017). Pengembangan Media Interaktif Menggunakan Adobe Flash CS 6 Pada Mata Pelajaran Menganalisis Rangkaian Listrik. Diakses pada 14 Februari $2020 \quad$ dari https://docplayer.info/69845072-

Pengembangan-media-interaktifmenggunakan-adobe-flash-cs-6-padamata-pelajaran-menganalisis-rangkaianlistrik.htm

Mardapi, Djamari. (2008). Teknik Penyusunan Instrumen Tes dan Non Tes. Yogyakarta: Mitra Cendikia.

Mustarin, Amirah, dkk. (2019). Penerapan Media Pembelajaran Adobe Flash CS6 Dalam Meningkatkan Hasil Belajar Siswa Kelas X ATPH Pada Mata Pelajaran Alat Dan Mesin Pertanian Di SMKN 4 Jeneponto. Diakses pada 20 Juli 2020 dari https://ojs.unm.ac.id/ptp/article/viewFile/8 $189 / 4729$

Purnama, Bambang Eka. (2013). Konsep Dasar Multimedia. Yogyakarta: Graha Media.

Rusman. (2012). Belajar dan Pembelajaran Berbasis Komputer. Bandung: Alfabeta.

Sakira. (2017). Simulasi Rangkaian Elektronika Daya Dengan Aplikasi Fluidsim 5.0 Electronic. Jakarta: Direktorat Pembinaan Sekolah Menengah Kejuruan.

Simarmata, Janner, dkk.. (2018). Learning Application of Multimedia-BasedComputer Network Using Computer Assisted Instruction Method. Diakses pada 19 Juli $2020 \quad$ dari https://www.researchgate.net/publication/3 26893828_Learning_Application_of_Multi media-Based-

Computer_Network_Using_Computer_Ass isted_Instruction_Method/link/5b8fc99292 851c6b7ec09319/download

Sriadhi, dkk. (2017). The Effect of Tutorial Multimedia on the Transformator Learning Outcomes Based on the Students' Visual Ability. Diakses pada 19 Juli 2020 dari https://www.researchgate.net/publication/3 26350556_The_Effect_of_Tutorial_Multi media_on_the_Transformator_Learning_O utcomes_Based_on_the_Students'_Visual_
Ability/link/5b4758b10f7e9b4637cf1556/d ownload.

Sriadhi. (2015). Analisis Karakteristik Media Pembelajaran Dan Motivasi Berdasarkan Gaya Belajar Siswa Sekolah Menengah Kejuruan. Diakses pada 19 Juli 2020 dari http://digilib.unimed.ac.id/19470/1/Fulltext .pdf

Sriadhi. (2018). Instrumen Penelitian Multimedia Pembelajaran. Medan: UNIMED.

Sudirman, Arif, dkk.. (2014). Media Pendidikan, Pengertian, Pengembangan, dan Pemanfaatannya. Jakarta: Rajawali Pers.

Sudjana, Nana \& Ahmad Rivai. (2009). Media Pengajaran. Bandung: Sinar Baru Algesindo.

Sugiyono. (2015). Metode Penelitian Pendidikan (Pendekatan Kuantitatif, Kualitatif, dan $R \& D)$. Bandung: Alfabeta.

Supriatna, Dadang dan Mochammad Mulyadi. (2009). Konsep Dasar Desain Pembelajaran. Jakarta: Pusat Pengembangan dan Pemberdayaan Pendidik dan Tenaga Kependidikan Taman Kanak-Kanak dan Pendidikan Luar Biasa.

Suyanto dan Asep Jihad. (2013). Menjadi Guru Profesional. Jakarta: Esensi.

Wati, Ega Rima. (2016). Ragam Media Pembelajaran. Jakarta: Kata Pena. 